\title{
A AÇÃO DO HOMEM ENQUANTO PONTO FUNDAMENTAL DA GEOLOGIA DO TECNÓGENO: PROPOSIÇÃO TEÓRICA BÁSICA E DISCUSSÃO ACERCA DO CASO DO MUNICÍPIO DE SÃO PAULO
}

\author{
ALEX UBIRATAN GOOSSENS PELOGGIA*
}

\begin{abstract}
THE HUMAN ACTION AS THE FUNDAMENTAL POINT OF TECHNOGENE GEOLOGY. The essence of Technogene Geology resides in the effective consideration of the man as geological agent, in addition to the consideration of human activities establishment - and in particular the activity mainly human, the production of its livelihood - regarding certain conditions of relief and substratum. The fundamental point that let us treat the man as such is the comparision of his activities with the resulting effects of natural causes of exogenous processes over the earth surface, for instance the climatic changes. Such eomparisons have already been shown by several authors, mainly in respect to the rapid erosion induced by agricultural praetiees. In short, the human action over the nature has geological-geomorphologic consequences concerning to three approach leveis: in the relief modification and physiographieal changes (technogenic reliefs); changes in landscape physiology (creation, induction, intensification or changes in exogenous processes behavior); in the creation of superficial correlative deposits (technogenic deposits), that is to say, setting themselves up as stratigraphical limits. However, the action of the man as geological agent introduces something essentially new, that differentiates him from ali other types of agents and geological factors: the ontological labor category. While factors essentially natural happen through causal chains, the human action happens through teleological postures, purposes, objectives previously idealized (even if the results of this action do not necessarily correspond to the preset objectives and many times even otherwise, since such results is a resultant from a produtive alienated activity).Technogenic deposits are linked to processes resulting from human types of relief appropriation, and, due to the originality of this determination, their existence Period characterize a distinct geological age: Quinary or Technogene. However, the Quaternary to Technogene passage, on stratigraphical point of view, is not homogenous, due exactly to temporal discrepancy (heterocrony) on the development and spreading of the technique through the planet and regions. It is in urban areas that the processes resulting from human transformation action over the nature concentrate and intensify. In the alluvial plains or hillsides of the city of São Paulo can be identified processes and deposits, that is a resut not from natural legality rupture but from changes in the category (while patterns of existence of these natural beings) from natural to humanized forni.
\end{abstract}

Keywords: human action, technogenic deposits, Urban Geology.

\begin{abstract}
RESUMO $\mathrm{O}$ cerne da Geologia do Tecnógeno encontra-se, além da consideração do estabelecimento das atividades humanas -e em particular a atividade essencialmente humana, a produção de seus meios de existênciasobre condições de relevo e se substratos determinadas, encontra-se na consideração efetiva do homem como agente geológico. E o ponto fundamental que permite tratarmos o homem como tal e a possibilidade de comparação dos efeitos das ações humanas aos efeitos resultantes das causas naturais da dinâmica externa sobre a superficie terrestre, como por exemplo as mudanças climáticas. Tais comparações já têm sido apresentadas por diversos autores, e principalmente, em nosso meio, no que diz respeito à erosão acelerada por atividades agrícolas. Em síntese, a ação humana sobre a natureza tem consequências geológico-geomorfológieas referíveis a três níveis de abordagem: na modificação do relevo e alterações físiográficas (relevos tecnogênieos); em alterações da fisiologia das paisagens (criação, indução, intensificação ou modificação do comportamento dos processos da dinâmica externa); na criação de depósitos superficiais correlativos (depósitos correlativos), ou seja, constituindo-se em marcos estratigráficos. No entanto, a atuação do homem enquanto agente geológico introduz algo essencialmente novo, e que o diferencia de todos os demais tipos de agentes e fatores geológicos: a categoria ontológica trabalho. Enquanto os fatores essencialmente naturais funcionam através de cadeias causais, a ação humana se dá através de posições Ideológicas, finalidades, objetivos pré-idealizados (e mesmo que os resultados dessa ação não necessariamente correspondam aos objetivos pré-fixados, e muitas vezes mesmo ao contrário, enquanto resultantes de uma atividade produtiva alienada). Os depósitos tecnogênicos são correlativos aos processos decorrentes das formas humanas de apropriação do relevo e, devido à originalidade dessa determinação, sua época de existência por decorrência caracteriza um tempo geológico distinto: o Quinário ou Tecnógeno. No entanto, a passagem do Quaternário ao Tecnógeno, do ponto de vista estratigráfico, não é homogénea espacialmente, em decorrência justamente da discrepância temporal (heterocronia) do desenvolvimento e difusão das técnicas pelo planeta e pelas regiões. E é nas áreas urbanas que os processos decorrentes da ação transformadora, socialmente produzida, do homem sobre a natureza se concentram e intensificam. Nas planícies ou encostas do Município de São Paulo identificam-se processos e depósitos que resultam não de quebras da legalidade natural, mas de mudanças de categoria (enquanto formas de existência desses entes naturais), da forma natural para a humanizada.
\end{abstract}

Palavras-chave: ação humana, depósitos tecnogênicos, Geologia Urbana.

"(...) Enquanto existirem homens, a história da natureza e a história dos homens se condicionarão reciprocamente" (Karl Marx \& Friedrich Engels, A Ideologia Alemã)

"(...) às vezes já se foram todas as coberturas, às vezes já estão perturbados todos os ciclos (...)" (Aziz Ab'Saber, Aspectos do Planejamento do uso e ocupação do solo) 
INTRODUÇÃO A ação do homem sobre a natureza, através da atividade produtiva, tem produzido efeitos geológicos (entendidos em sentido amplo, geomorfológico inclusive) que se acumulam em quantidade e se diversificam em qualidade, a ponto de ter sido proposta a designação de um novo período geológico para caracterizar tal época: o Quinário ou Tecnógeno. A Geologia do Tecnógeno concentra-se, então, no estudo dos produtos (depósitos e feições, ditos tecnogênicos) gerados diretamente ou influenciados pela atividade humana, mas também de seus processos específicos, estes que atuam sobre os próprios depósitos tecnogênicos assim como sobre maciços e relevos pré-existentes.

De forma breve, pode ser dito que a ação humana sobre a natureza tem consequências referíveis a três- níveis de abordagem ${ }^{1}$, em termos de formas, processos, formações e depósitos superficiais do ambiente geológico:

1. Na modificação do relevo e alterações fisiográficas da paisagem (por exemplo, retificações de canais fluviais, terraplanagem, voçorocas, áreas erodidas ${ }^{2}$, áreas mineradas etc.). Ter-Stepanian (1988) refere-se a tais efeitos como "novos tipos de relevo tecnogênico"; Fanning \& Fanning (1989) chamam de "superficies decapadas" (scalped land surfaces) a estas paisagens resultantes da ação do homem como agente geomórfico.

Em relação à classificação taxonômica das formas de relevo estabelecida por Ross (1992), as formas geradas por processos gerados ou induzidos pela atividade humana (processos tecnogênicos) corresponderiam essencialmente ao sexto taxon, o qual engloba "as formas menores produzidas pelos processos atuais ou por depósitos atuais. (...) as voçorocas, ravinas, cicatrizes de deslizamentos, bacias de sedimentação atual, assoreamentos (...) frutos dos processos morfogenéticos atuais e quase sempre induzidos pelo homem", ou "às pequenas formas de relevo que se desenvolvem por interferência antrópica ao longo das vertentes". No entanto, é possível relacionar as consequências da ação humana ao quinto taxon (formas de vertentes contidas em cada forma de relevo: encostas terraplanadas e mineradas, aterros) e mesmo ao quarto taxon (formas de relevo individualizadas dentro de cada unidade morfológica: é o caso das planícies fluviais aterradas e dos morrotes artificiais, como os grandes aterros sanitários). Na opinião de Abreu (1982), "(...) em muitos casos a dinâmica atual dos processos morfoesculturais está na dependência direta da sua ação [do homem], que se torna visivel já na escala de 1:200.000".

2. Em alterações na fisiologia das paisagens ${ }^{3}$ (os processos geomórficos, pedogênicos e sedimentares atuais): criação, indução, intensificação ou modificação do comportamento de processos da dinâmica externa (incremento da erosão e da carga sedimentar correlativa, escorregamentos em geral, infiltração e escoamento, drenagem pluvial e fluvial, taxas de sedimentação, fluxos subterrâneos etc), de porte comparável aos resultantes de variações climáticas ou efeitos tectônicos; nas áreas urbanas, resultando em uma outra organização da fisiologia da paisagem criada pelo construtivismo. Conforme já observava Ab'Saber (1969), "evidentemente, variações sutis de fisiologia podem ser determinadas por ações antrópicas predatórias, as quais na maior parte dos casos são irreversíveis em relação ao "metabolismo"primário do meio natural".

3. Na criação de depósitos superficiais correlativos ${ }^{4}$, comparáveis aos quaternários (os depósitos tecnogênicos 5 ), os quais vão se constituir em marcos estratigráficos: este caráter é indiretamente ressaltado por Fanning \& Fanning (1989): "Do ponto de vista de gênese dos solos, a destruição e formação de solos pelo homem, pela grande manipulação fisica dos materiais terrosos, são eventos catastróficos que criam novos pontos de partida para a formação dos solos" (tradução minha).

Ao conjunto desses níveis de ação denomina-se tecnogênese.

Nesse contexto, Goudie (1990) descreve o papel humano na criação de formas de relevo e na modificação do modo de operação de processos geomorfológicos, como intemperismo, erosão e deposição. Elenca tal autor formas produzidas pelo que denomina processos antropogênicos diretos (atividades construtivas, escavações e mineração e interferências hidrológicas) e indiretos (aceleração da erosão e sedimentação, subsidóencias, movimentos de massa, geração de sismos).

Já o soviético Ter-Stepanian (1988) estabelece um quadro de correlação entre processos naturais (no caso a ação de fatores geológicos) e tecnogênicos (ação do homem neolítico e moderno), da qual nos interessa ressaltar alguns processos exógenos (adaptação e tradução minhas):

-intemperismo fisico: desmonte de rochas em minas e construções;

-formação de relevo: modificação do relevo pela atividade mineraria e construtivismo;

-denudação: escavações e transferência de solos; -acumulação subaérea: aterramentos;

- erosão fluvial e acumulação subaquosa: mudanças na distribuição de depósitos fluviais por estruturas hidráulicas;

-formação de meandros (padrões fluviais em geral): retificação de rios:

-formação de escorregamentos, quedas de blocos e corridas de lama em processos denudacionais de vertentes: formação de escorregamentos, quedas e corridas devido a pressões neutras, escavações e sobrecarregamentos de taludes e encostas;

-sedimentação: formação de depósitos tecnogênicos.

Em complementação à síntese de Ter-Stepanian, resta talvez acrescentar dois fenômenos; o primeiro, por assim dizer, semi-endógeno, trata-se dos sismos induzidos, ou seja, os casos de terremotos provocados pela construção de represas e outras obras de engenharia, escavações mineiras ou injeções de água e resíduos líquidos em camadas profundas (UNESCO 1976, Torres et al. 1995); o segundo é a recarga artificial dos aquíferos através dos vazamentos dos sistemas de adução de água e afastamento de esgotos.

1 Tomamos como referência de partida as proposições metodológicas de Ab'Saber, (1969), para os estudos sobre o Quaternário.

2 O clássico relevo cárstico, matéria de estudo obrigatório nos bancos acadêmicos de Geologia e Geografia Física, ele mesmo, na forma como se apresenta em sua área típica (o deserto montanhoso do Karst às costas do Adriático) foi grandemente influenciado pelo desflorestamento, que deixou a rocha calcária, exposta à dissolucão, ser carcomida pela erosão (Thiel 1964). De fato, conforme o autor citado, as próprias estacas utilizadas para servir de alicerce a Veneza provêm daquela floresta devastada.

3 A paisagem, assim tratada, corresponde a uma expressão natural concreta e objetiva, sendo possível portanto tratá-la em termos ontológicos.

4 Depósitos correlativos são "sequências sedimentares resultantes dos processos de agradação ocorrendo simultaneamente com fenômenos de degradação na área fonte" (Bigarella \& Mousinho, 1965). Ainda, "representam um ciclo de erosividade sobre massa erodivel, e cujos sedimentos são depositados representando as condições hidrológicas do transporte e da área fonte (Princípio das Séries Inversas)" (Ab'Saber, 1990, comunicação verbal).

5 Aterros, depósitos de "bota-fora", coberturas remobilizadas, depósitos de assoreamento e outros,ou ainda, como pode ser encontrado na literatura norte-americana, solos influenciados pelo homem - man-influenced soils. A classificação pormenorizada desses depósitos pode ser encontrada em Peloggia (1996). 
A originalidade e a particularidade da ação geológica humana Deve ser ressaltado que a atuação do homem como agente geológico apresenta um caráter essencialmente novo, e que o diferencia de todos os demais tipos de agentes e fatores geológicos, em sua ação sobre a natureza (esta tornando-se então uma natureza transformada).

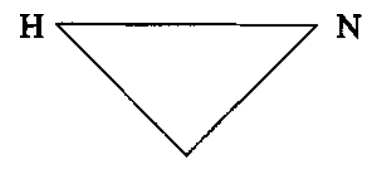

I

Conforme destaca Peloggia (1995), um necessário e suficiente esclarecimento sobre esta questão pode ser buscado na análise de Mészáros (1981) acerca da teoria marxiana da alienação: "para uma compreensão da 'essência humana da natureza, ou essência natural do homem', o conceito de 'atividade produtiva' (ou 'indústria' - que passamos a usar, pela sua brevidade) é de importância crucial. A 'indústria' é ao mesmo tempo a causa da crescente complexidade da sociedade humana (criando novas necessidades ao mesmo tempo que satisfaz outras mais antigas: 'o primeiro ato histórico é a produção de novas necessidades') e o meio de afirmar a supremacia do homem - como 'ser universal' que é ao mesmo tempo um 'ser especifico' - sobre a natureza. (...) Assim, Marx retraía a relação entre o 'homem' $(H)$, a 'natureza' (N) e a 'indústria' (I) na forma de uma interação tríplice entre suas partes constituintes. Isso pode ser ilustrado da seguinte maneira:

Como podemos ver, temos no caso uma reciprocidade dialética (...) entre os três membros dessa relação, o que significa que o 'homem' não é apenas o criador da indústria, mas também seu produto. Da mesma forma, ele é ao mesmo tempo produto e criador da 'natureza verdadeiramente antropológica' - acima de tudo em si mesmo, mas também fora de si, na medida em que deixa sua marca sobre a natureza. E como a relação entre o homem e a natureza é mediada através de uma forma alienada de atividade produtiva, a 'natureza antropológica 'fora do homem traz as marcas dessa alienação de forma cada vez mais acentuada (...)".

Chasin (1995) reafirma essas conclusões ao escrever que "(...) Marx rompe com a concepção excludente entre natureza e sociedade, pondo em primeiro plano o metabolismo humano-societário que as relaciona, no qual a primeira se apresenta como plataforma natural, que a sociabilidade transforma sem cessar em sua auto-edificação cada vez mais puramente social, consumando o progressivo 'afastamento das barreiras naturais', que tipifica o auto-engendramento do ser humano, no sentido da presença necessária, mas não determinante da natureza na infinitude intensiva e extensiva dessa identificação".

Deve ser ressaltado que em decorrência da ação humana não há quebras da legalidade natural (uma vez que as leis naturais não se modificam historicamente), mas mudanças de categoria (enquanto formas de existência) dos entes naturais, para as formas humanizadas . Conforme Lukács (sem data): "(...) o homem que trabalha pode inserir as propriedades da natureza e suas leis de movimento no interior de combinações inteiramente novas, pode emprestar a elas novas funções, novos modos de operar. Todavia, dado que esse processo só se pode realizar no interior de leis naturais irrevogáveis, a única modificação das categorias naturais pode consistir apenas no seguinte: que essas categorias - em sentido ontológico - passam a ser colocadas [enquanto finalidades]: esse fato de serem colocadas é mediatizado pela subordinação delas ao agirfinalístico que é determinante e que é, ao mesmo tempo, o meio através do qual, a partir da interação de causalidade e teleologia, surge um objeto, um processo, etc., unitários e homogêneos". Explica em outras palavras o mesmo Lukács (in Holz et al. 1969): "Uma das características essenciais da posição teleológica consiste na sua capacidade de deixar interagir, com a ajuda do conhecimento dos ordenamentos causais, estes mesmos ordenamentos causais da natureza numa outra combinação, diversa daquela que se realizaria caso não existisse a posição teleológica: os nexos causais, porém, só podem ser conhecidos e utilizados, mas não mudados". As mesmas considerações a respeito da legalidade do objeto são feitas por Chasin (1995), ao tratar que "(...) a natureza desta [legalidade] não muda ao ser acionada pelo sujeito, mas o modo e a direção em que é posta a funcionar dependem, inteiramente, da iniciativa deliberada daquele, sem a qual nenhuma transformação do tipo pode se verificar".

Ainda conforme Lukács (1979): "O homem que trabalha utiliza as propriedades mecânicas, fisicas e químicas das coisas, afim defaze-las atuar como meios para poder exercer seu poder sobre outras coisas, de acordo com sua finalidade. Os objetos naturais, todavia, continuam a ser em si o que eram por natureza, na medida em que suas propriedades, reações, vínculos etc., existem objetivamente, independentemente da consciência do homem; e tão somente através de um conhecimento correio, através do trabalho, é que podem ser postos em movimento (...)". Dessa forma, não é correio afirmar que o homem "introduz finalidades" na natureza, como quer atribuir Frederico (1995) ao pensamento marxista, mas sim que a relação homem-natureza é mediatizada através de posições teleológicas (tomadas de decisão entre alternativas). Nas palavras de Lukács (in Holz et al. 1969): "a natureza (tanto a natureza orgânica quanto a inorgânica) se desenvolve segundo a sua própria dialética e se realiza independentemente das posições teleológicas do homem".

Ter-Stepanian (1988) apreende tal particularidade da ação humana ao identificar a mudança fundamental que faré do homem pré-histórico um agente geológico diferenciado: a transição da apropriação dos alimentos à agricultura e criação pecuária, isto é, à produção de alimentos, no processo conhecido como Revolução Neolítica. Isto já se encontra determinado em Engels (1991), para o qual a atividade essencial dos homens, que os leva da animalidade à humanidade e constitui o fundamento material de todas as suas atividades, é a produção de seus meios de existência. E é pela pela produção que o homem exerce sua ação transformadora sobre a natureza, modificando-a e criando para si novas condições de existência. Ao mesmo tempo que sofre a ação poderosa da natureza, age sobre ela, aproveitando-lhe as possibilidades, tirando-lhes as vantagens, suprimindo-lhes os obstáculos, adequando-a às finalidades humanas. Em suma, humanizando-a.

\section{Consequências Geológicas das Ações Humanas no meio tropical do sudeste do Brasil: REVISÃO} TEÓRICA O ponto fundamental que permite tratarmos o homem como agente geológico é a possibilidade de comparação dos efeitos das acões humanas aos efeitos resultantes de causas naturais da dinâmica externa sobre a superfície terrestre, como por exemplo as mudanças climáticas ou, como o faz Watson (1983), à atividade orgânica: "o advento das sociedades industriais humanas tem trazido mudanças análogas àquelas iniciadas nos tempos paleozóicos pela evolução dos metazoários formadores de rochas ou no $\mathrm{Pa}$ - 
leozóico tardio pelo aparecimento das floras terrestres avançadas".

No nosso meio, comparações entre os efeitos naturais e de origem humana já têm sido apresentadas por vários autores, sob diferentes aspectos, mas principalmente no que diz respeito à erosão acelerada induzida por práticas agrícolas; faz-se necessário portanto recorrer a tais observações para prosseguirmos e fundamentarmos nossa análise. Conquanto esta digressão em alguma extensão repise caminhos já trilhados, devemos insistir em sua importância: nas palavras de Goethe (em Afinidades Eletivas), "soa mal, na verdade, ouvir-se a explicação de alguma coisa, que por si só se compreende, mas somente quando concordamos completamente com o conhecido, é que podemos avançar para o desconhecido".

$\mathrm{Na}$ verdade, é possível que o promeiro registro de processos e depósitos tenogênicos no Brasil seja aquele feito por Von Eschwege, em sua clássica obra Pluto Brasiliensis (publicada originalmente em 1833), ao tratar dos método sde mineração na região das Minas Gerais. Vejamos: "A princípio, fazia-se com certa facilidade a extração do ouro nos leitos dos rios e córregos, bastando, para isso, nos tempos das secas, em que as águas são em pequena quantidade, desviar o rio ou o córrego, o que se conseguia com muito menos dificuldade, porque a lama ainda não cobria os mais ricos sedimentos do leito, como aconteceu poucos anos depois. De fato, revolvendo-se frequentemente as cabeceiras dos rios, estes se carregam cada vez mais de lama, a qual se foi depositando sobre a camada rica, alcançando de ano para ano maior espessura, tal como vinte, trinta e até mesmo cinquenta palmos. Por este motivo, as dificuldades tornaram-se tão grandes, que não se pôde mais atingir o cascalho virgem " (Eschwege 1979). Por sua vez, Dean (1996) lembra que Euclides da Cunha, em 1901, registrava, em seus ensaios "Fazedores de desertos" e "Entre as ruínas", as voçorocas e a exposição de rocha viva que testemunhavam o abandono das plantações de café, havia uma geração, entre o Rio de Janeiro e São Paulo.

Seja como for, só em tempos mais recentes a descrição da ação geológica ou geomorfológica do homem tornou-se mais frequente na literatura, englobando-se em uma visão mais geral. Ab'Saber (1977), por exemplo, escreve que "no domínio dos 'mares de morros' e paisagens correlacionadas do Sudeste e Centro-Sul do País, registram-se os maiores problemas de erosão dos solos e lesionamento da paisagem de todo o Brasil". [Em um processo que se inicia com a retirada da cobertura vegetal de grandes setores dos morros, sobretudo a partir da introdução da cafeicultura] /.../ "Muitos fatares respondem por esta fragilidade do suporte geoecológico regional: o caráter rugoso e mamelonizado da topografia dos morros, a profunda e quase universal decomposição das rochas cristalinas (granitos, gnaisses, xistos) e, sobretudo, a existência de uma cobertura vegetal primária, densa e contínua. /.../ Um tal quadro paisagístico, sujeito a uma evolução integrada completa, comportou sempre um paradoxo: tratava de um quadro natural típico de biostasia e, entrementes, permanentemente sujeito às ameaças de uma resistasia antrópica. Mais do que qualquer outro domínio morfoclimático e fitogeográfico, esta foi a área menos resistente às ações antrópicas predatórias, imediatistas e pouco racionais" (Ab'Saber 1977).

Uma constatação semelhante, em essência, já havia sido feita por Engels há mais de 100 anos: "Aos agricultores espanhóis, estabelecidos em Cuba, que queimaram as matas nas encostas das montanhas (tendo conseguido, com as cinzas dai resultantes o adubo suficiente para uma só geração, para cafeeiros muito lucrativos), que lhes importava ofato de que, mais tarde, os aguaceiros tropicais provocassem a erosão das terras que, sem defesas vegetais, transformaram-se em rocha nua? /.../Os italianos dos Alpes, quando devastaram na sua vertente Sul, os bosques de pinheiros, tão cuidadosamente preservados na vertente Norte, (...) menos ainda suspeitavam que assim estavam eliminando a água das vertentes da montanha durante a maior pane do ano e que, na época das chuvas, seriam derramadas furiosas torrentes sobre as planícies" (Engels 1991).

Este caráter descrito por Engels é destacado por Tricart (1956). Conforme o geomorfólogo francês, o desenvolvimento do capitalismo, ao introduzir na agricultura a noção de lucro imediato, ao dar à economia rural uma forma especulativa, produzirá mudanças nunca antes vistas: "Nos países novos, a instalação dos brancos é traduzida por uma onda de morfogênese antrópica de uma rara violência. Formam-se ravinas, que corroem as vertentes e os terraços aluviais. Acumulações de lama entulham os fundos de vale. A terra cultivada se estraga quase que irremediavelmente (...). Toda uma morfogênese antrópica surge, a qual esculpe as formas de detalhe na massa real do relevo. /.../ Dessa morfogênese antrópica. importa conhecer suas leis: ela depende, ern uma fraca medida, das particularidades locais do solo e do clima e, numa medida bem maior, das formas de produzir" (Tricart 1956, tradução minha). Cailleux \& Tricart (1956) desenvolvem o mesmo tema, ao colocarem que "a ação do homem desempenha frequentemente um papel determinante na morfogênese atual, em função das modificações consideráveis que imprime à biosfera. Existe ainda toda uma série de formas antrópicas, desenvolvidas em consequência de uma ruptura de equilíbrio do meio natural desencadeada pelo homem. Elas variam em uma cena medida em função da zonalidade, mas não de uma maneira predominante, porque a ação do homem foi até aqui principalmente destrutiva. /... Também depende das formas técnicas e sociais de organização da produção ainda mais que do clima. A morfogênese antrópica tem sua dinâmica própria "(tradução minha).

Suguio \& Bigarella (1990), ao tratarem dos ambientes fluviais de sedimentação, associam a ocorrência de desequilíbrios mais ou menos graves a todas as interferências do homem na paisagem, sendo que entre diversos fatores, como as condições climáticas, a natureza do substrato, o gradiente hidráulico e a cobertura vegetal, a atuação humana mais significativa se dê nesta última: "O uso do solo e o desmatamento desenfreado vêm causando sérios problemas que tendem a agravar-se com o tempo". Em áreas urbanas, e portanto em escalas de análise maiores e bacias mais restritas, a atuação se dá também no fator substrato (terraplenagem intensa, retirada do solo superficial), gerando aumento de carga pela erosão acelerada. Sendo a declividade de um rio função da quantidade e textura dos detritos ou carga, a alteração dessa quantidade, resultante de incrementos erosivos, mantida a declividade, leva portanto ao assoreamento, acarretando a mudança do padrão fluvial (por exemplo, de meandrante a anastomosado ("braided channels"), bem como na capacidade de escoamento do vale) como reação de adaptação às novas condições. Mais ainda: em áreas urbanas, a mudança do padrão fluvial se dá, além de consequência induzida, por intervenção humana direta: retificação e canalização.

Vista essa necessária digressão, podemos ressaltar que o homem produz efeitos geológicos agindo de forma direta ou indireta. Talvez o melhor exemplo da última possibilidade sejam os fenômenos de deslizamentos por avalanche débris na Serra de Paranapiacaba (Estado de São Paulo), em janeiro de 1985, analisados por Ab'Saber(1987): "Após duas décadas de poluição aérea, por gases e particulados, através de uma 
marcha cumulativa e incontrolada, a vegetação da Serra de Paranapiacaba foi atingida em cheio por processos de degradação e fenecimento diferenciais". Para o autor citado, "trata-se de um dos exemplos mais dramáticos de perturbação local do ciclo hidrológico em um setor de escarpas tropicais, sujeito a um mecanismo de fortes chuvas orográficas. /.../ O caráter catastrófico das ocorrências esteve ligado a processos hidrometeorológicos, movimentos de massas de solos, regolito e biomassa vegetal; e, por fim, a processos hidrológicos, acompanhados de transporta e sedimentação fluviais, anômalos".

E justamente esse caráter original que nos interessa destacar: "Existe uma grande diferença entre o modelo natural de escorregamentos detectados ao longo da Serra do Mar - desde a época da construção da Via Anchieta [ ver por exemplo Vargas 1981 ] - e o modelo de avalanches detríticas ocorridas na Serra de Paranapiacaba. Os escorregamentos reconhecidos na "meia-serra" superior e na "meia-serra" inferior (...), eram de grande porte, muito isolados entre si, e gerados em épocas diferentes, dentro dos tempos históricos ou no interior do Quaternário. Foram gerados em pontos críticos de ordem geológica e geomorfológica, tendo tido, porém, o seu deslanche terminal relacionado a periodos de grandes "entradas " de água no solo e subsolo, por chuvadas excepcionais do passado. Chuvas ditas de "mil anos", na falta de maior precisão [ver, para a descrição dos tipos de movimentos de massa na Serra do Mar e seus mecanismos, por exemplo, Wolle (1988), Wolle \& Carvalho (1989)e Wolle (1992)]. Por sua vez, o quadro apresentado pelas avalanches débris da Serra de Paranapiacaba nos revela um sistema concentrado no espaço, segundo um modelo geométrico invariável, com deslanche terminal coletivo, efetuado em poucas horas de duração de chuvas muito fortes sobre tecidos geoecológicos fragilizados por uma insidiosa poluição aérea. Fato por suposto inexistente à época dos grandes landslides. isolados no tempo e no espaço" (Ab'Saber 1987).

Prossegue o autor: "A saída de materiais detríticos, predominantemente finos, para as verdadeiras planicies dos rios coletores das diferentes torrentes tropicais da serra, foi um acontecimento à parte no conjunto dos fatos observados na Serra de Paranapiacaba. As planícies de piemonte que comportavam rios meândricos, de volteado tranquilo, ao centro ou no lado de grandes várzeas, foram literalmente afogados pelo enorme volume de detritos chegados em massa, através de enchentes diluvianas. Cada torrente da serra injetou grandes massas de arguas, siltes, areias (que por sua vez envelopavam blocos de decomposição de rochas granitizadas $e$ os escombros de florestas escorregadas), alimentando a planície do Rio Mogi com uma carga detrítica não conforme com a aluviação tropical. Descreve o autor que a sedimentação espasmódica e anômala começou por arrasar a vegetação dos diques marginais do curso d'água e entulhar as rasas depressões das antigas várzeas, de modo a colocar massas detríticas, predominantemente minerais, sobre os solos fortemente orgânicos pré-existentes. Em decorrência, "logo os canais se desdobraram lateralmente ao leito principal do rio, sob o modelo trançado ou anastomosado ("braided channels"). eliminando as cicatrizes de antigos mendros e recheando o espaço total da planície pelos materiais provindos das avalanches débris. Por mera e paradoxal convergência criou-se temporariamente um quatro de sedimentação piemôntica. mais parecido com as grandes cheias de regiões secas, do que com áreas tropicais altamente chuvosas como é o casada Serra doMar- Como alertou Olga Cruz (...)para os depósitos do vale do rio Santo Antônio em Caraguatatuba, gerados em condições similares, não fosse termos a certeza de se tratar de um tipo de sedimentação anómala, nos sopés de serras tropicais chuvosas, alguém um dia poderia imaginar um depósito correlativo de um episódio seco, ligado a uma flutuação climática qualquer (...)" (Ab'Saber 1987).

Assim, é o caráter anômalo da sedimentação, decorrente da influência da ação humana (um "momento resistático antrópico") na geração dos processos de avalanches detríticas, que permite classificar os depósitos gerados na categoria de tecnogênicos induzjdos. Por outro lado, em outros países também são relatados casos em que o rompimento de estruturas humanas resultou em erosão e deposição extensivas: por exemplo a criação de extensos "leques aluviais", em período de poucas horas, resultantes do rompimento de barragens em áreas montanhosas (Blight 1991)

Particularmente sobre os excepcionais escorregamentos da Serra do Mar em Caraguatatuba (SP), ocorridos em 1967, descreve Ab'Saber (1985): " Utilizando os conceitos de Henri Erhart, relativos à biostasia e à resistasia, Olga Cruz designou os processos espasmódicos responsáveis pelos escorregamentos de Caraguatatuba sob o título sugestivo e correio de "momentos resistáticos". Isso implica dizer atuação rápida de uma morfogênese agressiva (resistasia) afetando um quadro de elaboração mais lenta e habitual de morfogênese e pedogênese, vinculados a um tipo especial de equilibrio ecológico, e a um particular sistema integrado de evolução paisagistica (biostasia) ".

Ressalte-se ainda que tais momentos excepcionais de morfogênese e sedimentação também relacionam-se à ação humana, e aqui de forma mais direta: "As grandes chuvas foram a mola básica do processo de avalanches de solo e rocha. Mas, certamente, as manipulações antrópicasprévias tiveram um papel importante na fragilização dos ecossistemas, criando condições diferenciais para osfatores de erosividade. A estrada de rodagem mal construída e sobretudo mal complementada por obras de arte e por projetos de paisagismo ecológico, reduziu as resistências naturais dos ecossistemas das vertentes escarpadas da Serra. Fato sobre o que não há qualquer dúvida". Conformo, o autor, isto se deu porque, com o aumento dos fatores de erodifailidade, os fatores de erosividade tiveram pma extraordinária ampliação no seu potencial de lesionarnentp. "A coalescência das lesões ao longo das vertentes serranas por onde passava a rodovia criou um outro padrão espacial de escorregamentos, bastante diverso daquele que incidiu sobre altas vertentes florestadas, onde o lesionamento teve o caráter de um sistema de reincisão dupla ao longo dos pequenos ramos das torrentes tropicais que formavam a bacia de recepção das águas serranas. Nos morros mais próximos da cidade, (...) as vertentes (...) estavam predispostas a escorregamentos por ocasião de grandes chuvas, devido à somatória de ações antrópicas inconscientes (...). Estas, como caracteriza o autor citado, encontravam-se ligadas a formas de ocupação e uso do solo, ligadas a empréstimos de terra, estabelecimento de barrancos na base dos morros, e outros procedimentos rotineiros, de extrema gravidade para a desestabilização de vertentes de morros situados em posição peri-urbana (Áb'Saber 1985).

Fúlfaro et al. (1976) descrevem que o material removido pelos escorregamentos (estimado em mais de 29 milhões de toneladas) foi em parte transportado para a baixada costeira, aí se depositando, em parte levado para o maré em parte depositado nas próprias encostas afetadas, sendo a espessura dos depósitos mais expressiva na pé-de-serra, diminuindo em direção ao mar. Não reconhecem tais autores no entanto a particularidade de tais processos, ou seja, a ação humana, correlacionando-os a fenômenos de movimentação de massa cíclicos, trimilenários, naturais, cujos registros preservam-se na coluna estratigráfica sedimentar da baixada litorânea. O mesmo ocorre com Petri \& Suguio (1971), que no entanto identificam nos materiais de preenchimento do vale do Rio Santo Antônio ora ausência de estratificações ou estratificações incipientes (nos depósitos de escorregamentos), ora características típicas de rios anastomosados (para sedimentos retrabalhados). 
Já na região do médio vale do Paraíba do Sul (SP/RJ), conforme Moura et al. (1992), assiste-se a um processo de retomada erosiva por sistemas de voçorocas remontantes (provavelmente tratando-se de um desdobramento o processo cujo início foi constatado por Euclides da Cunha), resultando em elevada taxa de sedimentação e assoreamento dos canais fluviais. Segundo os autores, tal processo configura uma fase de ajustamento dos sistemas fluviais, "certamente induzida ou intensificada pela ação antrópica ".

Ainda no que tange à erosão e ao assoreamento, a constatação dos depósitos tecnogênicos do Planalto Ocidental Paulista, em geral associados a voçorocas, descritos por Oliveira (1990) e Oliveira et al. (1992), "proporciona a configuração de um elemento de ligação entre os dois processos, fornecendo subsídios para se compreender que as perdas de solo por erosão não correspondem à produção de sedimentos de uma bacia e que o assoreamento não responde, portanto, deforma linear, à progressão da erosão. A ocorrência dos depósitos e seu entalhe mostra que não há uma condição contínua de erosão, transporte e deposição, mas sim saltos qualitativos que definem fases bem marcadas da evolução da paisagem " (Oliveira 1990). Tal evolução relaciona-se diretamente, segundo as próprias conclusões do autor citado, às formas de ocupação do solo e seu aproveitamento económico, inicialmente ao desmatamento para aproveitamento agrícola (café) ou para pastagens, associadamente a concentrações artificiais do escoamento. Os detritos resultantes das elevadíssimas taxas de erosão (facilitada pela presença de solos de elevada erodibilidade) passam a assorear as antigas várzeas. Por força do avanço da ocupação e uso do solo (intensificação da urbanização com pavimentação, mudanças no uso do solo agrícola etc.), tais depósitos passam a ser entalhados, eles mesmos, remontantemente na direção das fontes concentradoras do escoamento (em um claro exemplo de fenómeno dialético); os detritos produzidos aí por retrabalhamento e os de montante são transportados (e redepositados ao menos parcialmente) para jusante.

A descrição de Nakazawa et al. (1994a) converge no mesmo sentido, ao referir que, particularmente no Estado de São Paulo, "intensificando o desmatamento, a cafeicultura avança (sobre o espaço pioneiramente ocupado por culturas de subsistência e criação de gado) (...), primeiro ocupando o Vale do Paraíba, depois a região central do território paulista, seguindo, então, para o Norte do Estado (...). Os resultados deste desmatamento vertiginoso se refletem na intensificação do processo erosivo, no assoreamento das várzeas e drenagens, no aumento das áreas afetadas por inundações, na modificação do comportamento hídrico das vertentes e, generalizadamente, no empobrecimento do solo ". Aubert \& Boulaine (1967) já constatavam tal influência da monocultura no deslanchamento da erosão dos solos, através de vários exemplos mundiais e entre eles o brasileiro: "No Brasil, no Estado de São Paulo, se cultiva o café e o algodão desde o começo do século XIX; a cultura dura duas dezenas de anos e a seguir, deixando solos esgotados e à mercê da erosão cultiva-se mais a oeste. O resultado atual é que sobre 250.000 ha utilizáveis 170.000 estão muito degradados" (tradução minha). A validade geral dessas constatações é referenciada por Dean (1996): "No Sudeste, (...)na metade do século, observava-se também que rios, outrora límpidos e estáveis o ano todo, agora carregavam a água lamacenta escorrida das plantações; em seus estuários formaram-se bancos de areia que impossibilitavam até a navegação por canoas".

A relação entre a expansão agrícola, a erosão e a consequente geração de sedimentos já era esboçada em um re- latório de 1887, do $\mathrm{Eng}^{\circ}$. Bianchi Betoldi, reproduzido por Oliveira \& Figueirôa (1984): " Uma das causas das crescentes inundações observadas na alta Itália nesses últimos anos atribui-se ao levantamento do fundo dos rios proveniente do assentamento dos detritos que são levados continuamente pelas águas. E por essa razão com o correr dos anos e com o desmoronamento dos barrancos, hão de tornar-se sempre mais dificeis as condições de escoamento, a menos que não se trate seriamente de conservar e argumentar a zona bosquiva nas cabeceiras e nos vales afluentes. Este melhoramento é porém irrealizável na Província de São Paulo devido ao desenvolvimento sempre crescente da cultura de cana e do café e da grande e da pequena lavoura que importa a destruição das melhores florestas".

Desse modo, pode colocar Oliveira (1994), que o incremento notável na quantidade de sedimentos produzidos depois da introdução da agricultura intensiva, pastagens e outras formas de uso do solo responde à erosão responsável pela formação dos depósitos tecnogênicos de assoreamento. Considera o autor citado que "na bibliografia, essa erosão tem sido classificada como acelerada, antrópica ou atual. desencadeada pela ação do homem, que se expressa com velocidades muito superiores à erosão dita natural, geológica ou normal. (...) E a erosão marcadamente induzida pela ação humana, de tal maneira que não é mais possível identificar, nas regiões com alguma forma de uso do solo, processos erosivos exclusivamente naturais" (grifos meus).

Quanto a este aspecto de nosso interesse, no entanto, Aubert \& Boulaine (1967) haviam distinguido dois tipos extremos de evolução do relevo: a erosão geológica, na qual a velocidade de desgaste é lenta o suficiente para que a velocidade de formação dos solos por decomposição das rochas compense as perdas sofridas; e a erosão acelerada, devida ao ataque mecânico violento das rochas ou dos solos pelos agentes climáticos e à remoção imediata dos produtos desse ataque. Conforme os autores citados, os períodos de erosão geológica do solo referem-se aos períodos de biostasia (como vimos, quando o clima propicia que uma vegetação densa recubra o solo), por oposição aos períodos de erosão acelerada, ditos fases de resistasia (do grego rhexis, ruptura), os quais se produzem sobretudo depois dos movimentos tectônicos, das mudanças climáticas ou da intervenção do homem. Dessa forma, apesar de não relacionarem os fenómenos de erosão acelerada exclusivamente à ação humana, no entanto ressaltam os autores citados a equivalência dessa ação a processos naturais da maior significância.

Neste ponto podemos prosseguir com a análise de Oliveira (1994): "Esta forma de abordar os impactos da ação humana no meio ambiente aponta a expressão tecnogênico como mais rica na conceituação dos referidos depósitos. Portanto, a adoção deste termo, e do conceito implícito, está intimamente relacionada à percepção da expressão das mudanças provocadas pela ação do homem na superficie terrestre, comparáveis, em magnitude, às mudanças de origem natural" (grifo meu). Isto leva mais tarde o mesmo autor (Oliveira 1995) a propor o termo "abordagem geotecnogênica" para caracterizar esse estudo. Proposição de caráter epistemológico e, em si, não isenta de controvérsias ${ }^{9}$.

Visto isso, para sintetizar as observações relatadas podemos nos reportar à conclusão, embora bastante prudente quanto à potencial intensidade dos processos, de Ab'Saber (1969): Na verdade, a intervenção humana nos solos responde por complexas e sutis variações na fisiologia de uma determinada paisagem, imitando até certo ponto os acontecimentos, de maior intensidade e extensividade, relacionados às variações climáticas quaternárias". Conclusão esta que é confirmada praticamente nos mesmos termos por Melo \& Ponçano (1983): "A ação antrópica atual tem desen- 
cadeado consequências comparáveis às de uma das últimas fases de clima seco, determinando, por exemplo, o desenvolvimento de boçorocas atuais sobre os mesmos sítios em que feições semelhantes haviam se desenvolvido durante a fase seca correlativa da glacial Würm".

O Período Quinário ou Tecnógeno A interação entre as atividades humanas e os processos originais do meio "natural" leva à configuração de uma realidade original e de expressivas consequências geológicas. Como vimos, os depósitos tecnogênicos são correlativos aos processos decorrentes das formas humanas de apropriação do relevo e, devido à originalidade desta determinação, sua época de existência por decorrência caracteriza um tempo geológico distinto ${ }^{10}$. Isto é justificado porque, em essência (recorrendo ao comentário de Lukács 1979), os períodos e as épocas (geológicos) definem-se por mudancas ou estabilidades estruturais de matéria ou movimento. Em outras palavras, caracterizam-se por processos determinados e seus registros correlativos. A originalidade do Período Tecnógeno ou Quinário consiste portanto em que, conforme sintetiza Oliveira (1995), "as novas coberturas pedológicas e as novas formações geológicas, que se encontram em processo de geração, estão fortemente influenciadas pela ação do homem".

Conforme descreve Oliveira (1990), "a expressão Antropógeno vem sendo usada por alguns autores, sobretudo soviéticos (ver por exemplo Gerasimov \& Velitchko 1984), em substituição ao termo Quaternário, para indicar o período geológico mais recente, marcado pela evolução do homem (...). Eventos ditos antropogênicos seriam, sob este enfoque, identificados ao período de sua ocorrência, podendo ou não estar relacionados às atividades humanas. Portanto, para definir uma origem ligada à atividade do homem, seria mais conveniente usar o termo tecnogênico. Assim, todo evento tecnogênico (origem) seria antropogênico (período), o inverso não sendo necessariamente verdadeiro. Por outro lado, o termo tecnogênico (originado pela técnica) destaca a importância em se considerar que os eventos resultantes da ação humana refletem uma "ação técnica" e, neste aspecto, sua adoção tem larga vantagem sobre a do antropogênico, pois a técnica, conjunto dos processos por meio dos quais os homens atuam [através do trabalho, ressaltamos] na produção econômica e qualquer outra que envolve objeos materiais, surge com o homem" ./.../ "Quinário ou Tecnógeno" [seria então] "o período em que a atividade humana passa a ser qualitativamente diferenciada da atividade biológica na modelagem da Biosfera, desencadeando processos (tecnogênicos) cujas intensidades superam em muito os processos naturais" (Oliveira 1990). Ou, propomos, processos cujas intensidades podem superar em muito os processos naturais equivalentes. No entanto, deve ser lembrado mesmo que, ao contrário, a ação humana pose se efetuar no sentido da amenização dos processos naturais, como nas áreas de estabilidade morfodinâmica de origem antrópica definidas por Ross (1991).

Segundo Ter-Stepanian (1988), as modificações impressas pelo homem na natureza geológica, a partir do início da produção agrícola e pastoril da chamada Revolução Neolítica (a nove ou dez mil anos atrás em algumas partes do planeta), como vimos, e progressivamente intensificados, até as modernas e profundamente transformadas regiões industrializadas, mostram que o Holoceno pode ser considerado como uma época de transição entre o Quaternário (Pleistoceno) e o Quinário ou Tecnógeno. O começo dessa época é caracterizado por uma situação totalmente quaternária, e seu fim por uma situação totalmente quinaria, a qual deve se completar, segndo a autor, no próximo milénio, caracterizando uma mudança muito mais rápida que a dos períodos geológicos anteriores.

Vemos aqui então que a passagem do Quaternário ao Quinário ou Tecnógeno, do ponto de vista estratigráfico, não é homogénea espacialmente, em decorrência justamente da discrepância temporal (heterocronia) do desenvolvimento e difusão das técnicas pelo planeta e pelas regiões ${ }^{12}$. Assim, a "Revolução Neolítica" iniciou-se a aproximadamente nove mil anos atrás nos orientes Próximo e Médio e no Sudeste da Ásia, entre cinco e oito mil anos atrás na Europa, e a seis mil anos atrás na América Central (Kowalski 1984).

Conforme Castri (1980), na região mediterrânea há 3.500 anos já se produziam importantes fenômenos de desflorestamento; ainda conforme o autor citado, o desflorestamento intensivo na China começou há quatro mil anos. Em várias partes do mundo, e em grande parte da América, tal papel será realizado, ou melhor, superado, pela colonização europeia (o que Dean 1996, chama de "a segunda leva de invasores humanos"). Note-se no entanto que Castri (1980) ressalta a ocorrência anterior de desmatamento pré-histórico relacionado à utilização do fogo para limpeza de terrenos de caça. Na Mata Atlântica Brasileira, Dean (1996), além de relatar a ação dos grupos indígenas caçadores-coletores, queimando tanto a margem da floresta quanto o cerrado para afugentar e atrair caça, assinala a derrubada da floresta pelos

9 A "abordagem geoíecnogênica do meio fisico", na forma proposta por Oliveira (1995), apresenta uma contradição nos termos: tal abordagem, segundo o autor citado, "pode ser denominada geotecnogênica porque, mais que geológica, ela incorpora a compreensão do papel do homem como novo agente geológico". Ou seja, uma abordagem geológica. O problema é que não se trata de uma questão de método - no sentido gnosio-epistêmico-, como acreditamos pretender o autor (uma abordagen que se diferencie pela forma), mas de objeto. Isso não implica necessariamente em procedimentos geológicos novos na identificação dos processos e depósitos tecnogênicos, mas sim a consideração das determinações não-geológicas (sócio-econômico-culturais, enfim, humanas) de sua génese. A Geologia do Tecnógeno é uma disciplina ao mesmo tempo da história da natureza e da história humana, em função do inseparável relacionamento dialético entre ambas. No mais, é possível que tais posições decorram da própria base teórica dotada por Oliveira (calcada na obra $O$ Processo Civilizatorio, de Darcy Ribeiro), a qual enfatiza "o poder de determinação dos conteúdos tecnológicos sobre os sociais e ideológicos e quanto à possibilidade de seriar o desenvolvimento tecnológico em passos evolutivos do progresso humano". Historiadores soviéticos, como por exemplo Diacov \& Covalev (1965), já questionaramn a adequabilidade da utilização do "critério tecnológico" na classificação da história antiga da humanidade, por separar o desenvolvimento da técnica do desenvolvimento da sociedade. Nas palavras de Milton Santos: "O progresso tecnológico deve ser considerado à luz da história social fazendo-se sobre as técnicas. É como se [se] repetisse o que Marx disse: 'a técnica não é a economia', isto é, não é a sociedade" (Santos, 1989). Ou seja,se a tecnologia - a capacidade de transformar a natureza - é propiciada pela e reflete a evolução da sociedade, de forma alguma a sintetiza. No mesmo sentido afirma Lukács (in Holz et al., 1968): "Há quarenta anos polemizei contra a concepção bukariniana da técnica como força produtiva determinante; (...) a técnica foi sempre e apenas um meio no desenvolvimento das forças produtivas, que as forças produtivas em última análise são sempre os homens e as suas capacidades". Katz (1996), ao referir-se ao caráter social da tecnologia, escreve que, para o marxismo, "a mudança tecnológica é equivalente ao desenvolvimento das forças produtivas", ressaltando que "o caráter social da inovação obedece ao papel protagônico tanto das formas de trabalho como das relações de propriedade prevalecentes em qualquer transformação tecnológica", e que "a evolução de um instrumento de trabalho está configurada pelo regime social dominante".

$10 \mathrm{O}$ fato de que o período de existência do homem sobre o planeta é insignificante em relação à extensão do tempo geológico não é significativo, para o tema de nossa discussão, se levarmos em conta que sua ação transformadora sobre a natureza, além de diferenciada, é de central importância para a própria humanidade.

11 Trata-se, segundo o autor citado, de uma categoria de comportamento morfodinâmico, ou seja, uma zona em equilíbrio com estabilidade por urbanização e impermeabilização do solo.

12 A rigor, seria mais preciso falar na difusão das formações sociais e modos de produção aos quais as técnicas se relacionam e subsumem. 
grupos agricultores itinerantes (e.g. os Tupis), com as finalidades de assentamento, agricultura, comunicação e guerra. Sintetiza Rougerie (1971) que "desde o Neolítico, tornou-se o homem um fator ecológico dominante; nos setores por ele desmaiados foram se instalando paulatinamente as espécies provenientes dos espaços herbosos".

Como vimos nas descrições anteriores, na região centro-sul do país, em particular no Estado de São Paulo, é, em sentido amplo, o Ciclo Econômico do Café, com os processos de desmatamento, agricultura intensiva e urbanização decorrentes, o fato histórico marcante que pode ser identificado então ao início do Quinário, desde que configura-se na causa primeira da qual decorrem a intensificação dos processos erosivos e a formação dos depósitos tecnogênicos correlativos ${ }^{13}$. No caso específico do Município de São Paulo, embora seja considerado por alguns autores que os "Campos de Piratininga", clareira encontrada pelos colonizadores quinhentistas em meio à floresta subtropical, resultasse da prática de queimadas feitas pelos indígenas em épocas pré-cabralinas (França 1958, Ab'Saber 1961), não temos ainda a possibilidade de identificação dos depósitos tecnogênicos associados ao incremento erosivo resultante.

Implicações estratigráfiças No Estado de São Paulo, a "Classificação das Formações Cenozóicas" de Rego (1933) parece ser a primeira a caracterizar as consequências da ação humana sobre o registro estratigráfico, ao colocar as camadas "com restos humanos (depósitos)" no topo da coluna estratigráfica paulista, como andar superior das "camadas quaternárias modernas, consideradas atuais" (embora se refira o autor especificamente aos depósitos de "sambaquis" ${ }^{14}$ ). Referentes à região central da cidade de São Paulo, os cortes geológicos apresentados por Vargas (1992), executados em 1945 e 1947, são provavelmente os primeiros a representar os depósitos tecnogênicos (aterros, com espessuras atingindo localmente a ordem de $10 \mathrm{~m}$ ) sobre as camadas cenozóicas. Mais recentemente, autores como Rocha \& Celestino (1992), Yassuda et al (1992) e Cozzolino et al. (1994) apresentam seções geológicas da porção central da Bacia Sedimentar de São Paulo, nas quais se observam extensos, espessos e contínuos depósitos tecnogênicos de cobertura (também denomi- nados genericamente de aterros). Já perfis geológicos apresentados por Prandini et al. (1978), Cozzolino (1980), Chiossi (1980), Sampaio et al. (1992), Gonçalves \& Brollo (1993), Coutinho \& Negro (1995) e Takiya (1997), entre outros, embora referentes a situações localizadas e, portanto, apresentados em escalas maiores, assinalam a ocorrência contínua de aterros espessos sobre aluviões quaternárias ou sedimentos terciários. As seções geológicas da Bacia de São Paulo e as colunas estratigráficas apresentadas recentemente por Riccomini (1989), Riccomini \& Coimbra (1992) e Riccomini et ai (1992), no entanto, não consideram a expressão geológica de tais depósitos.

Mas, de fato, como demontra Peloggia (1996), nas planícies ou encostas paulistanas é possível identificar uma marcante discordância estratigráfica, na qual os depósitos tecnogênicos (induzidos ou construídos) posicionam-se respectivamente sobre os depósitos da planície de meandração holocênica e baixos terraços fluviais quaternários ou sobre os horizontes colúvio-eluviais-pedogênicos das vertentes. Poderíamos falar neste caso, de modo analógico, em "discordância paralela sem fase erosiva (hiatoV ou ainda "paraconformidade" (no sentido que lhes atribui Mendes 1984); esta, mais do que às datações paleontológicas, como na estratigrafia convencional, é reconhecida de maneira geral devido à presença de artefatos na camada tecnogênica (além de peculiaridades composicionais). Ressalte-se que não se tratam de meros diastemas (enquanto quebras localizadas do registro, dentro de um processo contínuo em sua totalidade), mas registram a substituição dos processos quaternários por processos completamente novos.

Nas principais planícies do município em enfoque a ocupação urbana foi propiciada pela retificação dos rios e córregos, que canalizaram os leitos em cursos retilíneos e de declividades muito superiores àquelas dos cursos meandrantes e, assim, quebraram definitivamente os processos naturais de funcionamento das planícies fluviais holocênicas. As amplas áreas de várzeas, antes alagadiças, assim liberadas, são ocupadas através de progressivos aleitamentos (desde pelo menos a primeira metade do século XIX, como demonstram as plantas municipais da época), a coalescência dos quais propicia um recobrimento quase completo das antigas

13 Ressalte-se que poder-se-ia tentativamente recuar tal transição, ao menos de forma localizada espacialmente, para a época do Ciclo do Ouro na região das Minas. Conforme ressalta Salles (1978), "(...) a exploração do ouro à época caracterizou-se por triplo caráter predatório: o manto vegetal e mesmo o solo foram destruídos repetidas vezes, acabando por nos legar o aspecto desolador de muitas regiões anteriormente auriferas". As implicações dessa ação na criação de depósitos sedimentares são adiantadas por Riccomini et al. (1991): "A influência antrópica deve ser considerada para os depósitos de trezentos anos de idade de MG, principalmente devido à atividade mineraria (exploração de ouro) [nessas áreas]" (tradução minha). No espinhaço Meridional, (Depressão de Gouveia, MG), Magalhães et al. (1992) registram uma significativa modificação no padrão de sedimentação fluvial durante o "Quaternário Tardio", com implantação e evolução de condições de entrelaçamento nos atuais canais fluviais. Dean (1996) (citando interessantes relatos de naturalistas do século XIX), relata que a lavra, ao efetuar o desnudamento das encostas, "provocou erosão de camadas de terra, gerando gigantescos sulcos chamados voçorocas, assoreamento de leitos de riahos e enchentes que ainda ocorrem na região mas que agora são tão generalizadas e antigas que parecem características naturais da paisagem". Estima o autor em cerca de quatro mil $\mathrm{km}$ a área de Mata atlântica devastada pela prospecção de ouro e diamantes no século XVIII.

No entanto, devem ser observadas algumas particularidades desse "ciclo"; como escreve Moreira (1990), "mas como a técnica primitiva de estrações e a busca de enriquecimento imediato levam a uma intensa mobilidade territorial dos mineiros, os centros de mineração se multiplicam com incrivel rapidez, dando ao espaço mineiro a sua forma de enorme nuvem de nebulosasas espalhadas pelo planalto central, e as lavras rapidamente se transformam emfaiscação. /.../ Quando termina o século XVIII, o planalto central-mineiro já não tem a mesma agitação de vida e o espaço mineiro sofre um refluxo econômico-demográfico tão rápido quanto o foi o surgimento do 'ciclo"'. Se os efeitos da atividade mineraria foram, portanto, localizados e transitórios, a atividade criatória pecuária, por seu lado, "pouco (...) altera o ambiente natural, nisso também contrastando, portanto, o espaço pecuário e o planíacionista, uma vez que, instalando-se nas áreas de mata, a lavoura provoca sua maciça derrubada, enquanto que o espaçopecuário acomoda-se de imediato ao pasto natual da vegetação campestre" (Moreira, 1990). Quanto às plantações açucareiras, descreve Dean (1996) que, até 1700, elas teriam eliminado érea de mil $\mathrm{km}$ da Mata Atlântica; conforme o autor, "era uma depredação modesta; na verdade, representava menos da metade da área atual do Município do Rio de Janeiro". Seja como for, ressalta Moreira (1990) que "na passagem do século XIX para o XX a cartografia já difere do que era o espaço brasileiro de apenas um século atrás. O mapa desse momento (...) mostra um arranjo espacial de manchas agrárias mais densas e com poucos claros. Mais que isso, um arranjo de manchas agrárias organizadas num novo eixo cidade-campo".

14 Descreve Dean (1996) que os sambaquis resultam do acúmulo de restos alimentares dos indígenas (anteriores aos Tupis) habitantes das regiões litorâneas de mangues. Tratam-se de pilhas de conchas de amêijoas, mariscos, mexilhões e ostras, que se extendem por até $300 \mathrm{~m}$ de comprimento e $25 \mathrm{~m}$ de altura. Conforme o autor, "Ao longo da costa, do Espírito Santo ao Rio Grande do Sul, muitas centenas dessas pilhas de conchas (...) foram encontradas, embora erodidas e cobertas por vegetação de restinga. Muitas mais cobriam outrora a costa, mas parte se perdeu pela ação de tempestades e correntes. Outras desapareceram nos últimos quinhentos anos, à medida que eram mineradas em busca de cal (...)". ... "O mais antigo sambaqui datado teve início a cerca de 8 mil anos, mas outros, ainda mais antigos, podem estar agora abaixo do nível do mar". 
planícies, dos meandros abandonados e do antigo leito, e ainda mesmo dos baixos terraços cascalhemos ${ }^{15}$.

Tal cobertura contínua, extensa e potencialmente mapeável, de espessuras comparáveis, pelo menos, aos aluviões holocênicos, constitui o representante mais evidente de uma formacão geológica quinaria no Município de São Paulo. $\mathrm{E}$, esta, de gênese intimamente ligada portanto à dos compartimentos de relevo associados, as planícies tecnogênicas. A "Carta Geotécnica dos terrenos adjacentes ao canal do Rio Tietê", em escala 1:1.000, apresentada por Prandini et al. (1978), representando uma faixa de $30 \mathrm{~km}$ de extensão da várzea entre Osasco e guarulhos, e baseada no impressionante número de aproximadamente 17.600 sondagens, fundamenta e referenda nossa tese. Conforme demonstram tais dados, é caracterizada uma cobertura de depósitos tecnogênicos (ali identificados como uma "unidade geológico-geotécnica": aterros), a qual "ocorre praticamente em todo o trecho [de 30 $\mathrm{km}] "$. Tal unidade, cujas espessuras, comparáveis ou superiores às das camadas aluvionares, alcançam até $6 \mathrm{~m}$ ou mais, conforme os autores citados é constituída por uma mistura aleatória de materiais argilosos, siltosos e arenosos das mais variadas procedências.

Seja como for, aos processos de aterramento das várzeas centrais vêm juntar-se as transformações induzias que acompanham via de regra as frentes de expansão urbana, notadamente naquelas regiões do Município onde estas avançam em direção às cabeceiras de drenagem: o excesso de carga sedimentar que a erosão aelerada conduz aos riachos sinuosos produz padrões semelhantes aos canais entrelaçados (braided channels) típicos das savanas.

Mais marcante no entanto se faz a discordância quando uma parcela do tempo geológico, representada pelos horizontes quaternários, é suprimida, por erosão induzida ou, simplesmente, por escavação, e os maciços remanescentes recobertos por depósitos tecnogênicos. Peloggia (1994) caracteriza, nesse sentido, as coberturas remobilizadas, disseminados capeamentos tecnogênicos de encostas urbanas. Realmente, conforme a descrição de Wolle \& Silva (1992), a escavação do horizonte de solo superficial natural (as "arguas verelhas porosas" dos geotécnicos), na Bacia Sedimentar de São Paulo, "é quase regra geral nos terrenos desocupados da cidade, pois esta argila porosa, por ser excelente material para aterro, foi extensamente explorada em toda a região". Caracteriza este caso, então, uma "discordância angular e erosiva" ou "inconformidade" (sensu Mendes 1984), na qual a ação humana faz o papel de "ciclo de erosão" associado.

A Geologia do Tecnógeno $e$ as áreas urbanas $O$ cerne da Geologia o Tecnógeno, enquanto ramo do conhecimento geológico, encontra-se, portanto, além da consideração do estabelecimento das atividades humanas -e em particular a atividade essencialmente humana, a produção de seus meios de existência - sobre condições de relevos e substratos determinadas, encontra-se na consideração efetiva do homem como agente geológico; tal abordagem trata, portanto, do desvendamento da ontologia própria do período Quinário ou Tecnógeno. E sendo os processos e depósitos tecnogênicos decorrentes da ação humana, a apreensão dos determinantes sócio-econômicos dessa ação balizará, necessariamente, a correlação que efetuarmos entre tais aspectos geológicos em si e sua importância enquanto objetos da aplicação científica.
É nas concentrações urbanas que a ação modificadora do homem sobre a natureza, por assim dizer, geológica, se amplia e diversifica, ganhando imediato interesse em função de afetar, direta ou indiretamente, a vida de grandes quantidades de seres humanos. Especificamente quanto a este aspecto comentam Nakazawa et al (1994b): "Aos problemas já desencadeados no campo, com a sua ocupação intensiva, a urbanização acelerada a partir da década de 50 agrega, com suas complexas interrelações entre a cidade e seu ambiente fisico, novos e variados problemas. Estes problemas se fazem sentir pelos sobrecustos da consolidação e manutenção das cidades, pela degradação ambiental e, também, pelo desconforto e risco de vida impostos a parcelas significativas da população. /.../ Erosões intensas, assoreamento de rios e de reservatórios, poluição de mananciais, escorregamentos em encostas e outros problemas induzidos pela urbanização tornam fundamental o entendimento dos processos de uso e ocupação do solo [e, adicionaríamos, suas determinações sócio-econômicas] - em associação com os processos do meio fisico - para o seu enfrentamento eficaz".

Abreu (1986) apresenta o exemplo específico da área metropolitana de São Paulo, onde "pode-se dizer, de maneira geral, que as propriedades geoecológicas originais do relevo estão quase todas modificadas pela intervenção humana que, frequentemente malbaratou também as propriedades sócioreprodutoras, dinamizando os processos morfodinâmicos. Este fato, aliás, tem se agravado cada vez mais, na medida [em] que a urbanização extravasa os limites da bacia sedimentar neocenozóica sobre a qual a cidade se originou". Na concepção do autor citado, "enquanto as propriedades geoecológicas se originam por processos biológios e morfodinâmicos, presididos pelas leis bio, fisico e geoquímicas que cunham as formas e lhes conferem conteúdo plástico, as propriedades sócio-reprodutoras são definidas pelo interesse imediato do homem pelo relevo como recurso, face ao seu conteúdo (solos, depósitos minerais e te.), ou como suporte de edificações de um espaço construído".

Por outro lado, conforme proposto por Peloggia \& Silva (1994), a Geologia Urbana poderia ser concebida como uma disciplina que tem por objeto a análise de fenómenos geológicos ou de condicionantes geológicos a fenómenos diversos associados ao processo de urbanizacão (à implantação, desenvolvimento e consolidação das cidades). Trata-se, portanto, de uma abordagem regional bastante específica e peculiar a cada sítio urbano estudado, dentro da Geologia do Tecnógeno. Pois, em particular, não se dissocia da ação humana que, através de seus meios de produção material (trabalho) e apropriação e utilização dos espaços superficial (relevo) e subterrâneo, impõe diferenciadas solicitações aos maciços, suportando então diferentes respostas (o que se costuma chamar de "comportamento geotécnico").

$\mathrm{Na}$ opinião dos autores citados, a caracterização dos tipos de fenômenos de natureza geológica (ou mesmo "geotécnica"16) em áreas urbanas, em particular os escorregamentos (entendidos em sentido amplo, como movimentos gravitacionais de massa), e a definição de sua natureza, seus mecanismos, forma de ocorrência e abrangência, constitui a base teórica necessária à aplicação, tal como nas concepções de medidas de estabilização de encostas e taludes, nas análises de riscos, na orientação para a implantação de projetos habitacionais e a recuperação de áreas degradadas; ou ainda potencialmente para as concepções de planos de defesa civil de

15 O histórico desse processo e as características básicas dos depósitos são detalhadamente descritos por Peloggia (1996).

16 "Existe a tendência, entre alguns autores, de conceituar os acidentes ou riscos geotécnicoscomo aqueles no qual o processo geológico em questão (em geral exógeno) atua num local onde existe a interferência de algum tipo de obra de engenharia. Desta forma, um escorregamento com danos que ocorra num talude natural será um Acidente Geológico, enquanto que este mesmo escorregamento num talude de corte, ou de um aterro, será um Acidente Geotécnico " (Augusto et al, 1990). Para Oliveira et al. (1995), "o uso da expressão geológico-geotécnico, comum na literatura técnica, é entendida [no contexto de] temas ou aspectos de natureza geológica considerados no âmbito da geotecnica". 
caráter preventivo e as orientações para uso e ocupação do solo ou, ainda, a um planejamento urbano racional. Graças ao caráter dinâmico da urbanização, podemos observar os processos de apropriação do relevo em andamento e, considerando as peculiaridades históricas, compreender as feições e depósitos das áreas já ocupadas.

CONSIDERAÇÕES FINAIS Se os pressupostos gerais necessários à análise acima definida têm sido esboçados recentemente, em Geologia, por alguns autores, como por exemplo Oliveira (1990) ("Frente às atuais formas de uso e ocupação do solo e seus impactos no meio físico, não será mais possível estudar os processos geológicos recentes sem considerar as profundas modificações que vêm sendo causadas pelo homem.") ou Prandini et al. (1974) ("Toda atividade humana está direta e indiretamente vinculada às condições subsuperficiais do planeta"), estas concepções não são, no entanto, novas, como demonstra Peloggia (1995). Ressalte-se ainda: são necessárias porém não suficientes pois, além dos efeitos da ação humana sobre o ambiente geológico, como vimos, a aplicabilidade concreta (isto é, que se efetiva em resultados práticos) deve levar em conta as práticas humanas em si, suas causas (ou seja, em última análise as causas que levam à indução dos problemas geológicos), motivações, tendências, como única forma de real possibilidade de proposição de soluções.

Isto se fundamenta simplesmente porque (tomando as palavras de Moraes (1994) ao analisar a concepção marxista da relação homem-natureza): "o instrumento técnico disponivel exprime as forças produtivas de uma dada sociedade, às quais corresponde uma certa divisão social do trabalho e relações de produção também especificas. São estas que definem as formas de apropriação da natureza e o acesso dos diferentes grupos sociais aos recursos do ambiente". Esclarece-nos Vaisman (1989): "[Conforme Lukács] (...) quanto mais desenvolvida, quanto mais social é uma formação econômica, tanto mais complexos são os sistemas de mediações que ela deve construir em si e em função de si, mas estes interagem todos de qualquer modo com a auto-reprodução do homem, com o intercâmbio orgânico com a natureza, permanecem em relação com ele e são ao mesmo tempo capazes de retroagir sobre ele, no sentido de favorecêlo ou obstaculizá-lo". Ou, conclusivamente, nas palavras do próprio Lukács (in Holz et al. 1969): "[Para Marx] os homens podem desenvolver uma ação transformadora sobre a natureza apenas no quadro da praxis humana, e (...)fora isso, a natureza se desenvolve independentemente do homem".

\section{REFERÊNCIAS}

Abreu, A. A. 1982. Análise Geomorfológica: reflexão e aplicação. São Paulo, 296 p. (Tese de Livre Docência, Faculdade de Filosofia, Letras e Ciências Humanas da Universidade de São Paulo).

Abreu, A. A. 1986. Ação antrópica e propriedades morfodinâmicas do relevo na área metropolitana de São Paulo. Orientação, Instituto de Geografia / Departamento de Geografia, USP, 7:35-38.

Ab'Saber, A.N. 1961. O problema das paisagens originais do sítio urbano de São Paulo. Notícia Geomorfológica 4:52-55.

Ab'Saber, A.N. 1968. Bases geomorfológicas para o estudo do Quaternário no Estado de São Paulo. São Paulo, 212 p., (Tese apresentada ao concurso da Cadeira de Geografia Física da Faculdade de Filosofia, Ciências e Letras da Universidade de São Paulo).

Ab'Saber, A.N. 1969. Um conceito de Geomorfologia a serviço das pesquisas sobre o Quaternário. Instituto de Geografia, Universidade de São Paulo, Geomorfologia, 18, 23 p., São Paulo.

Ab'Saber, A.N. 1977. Problemática da desertificação e da savanização no Brasil intertropical. Instituto de Geografia, Universidade de São Paulo, Geomorfologia, 53, 19p., São Paulo.

Ab'Saber, A.N. 1985. A gestão do espaço natural (relembrando Caraguatatuba - 1967 - para compreender Cubatão - 1985). $A U$ Arquitetura e Urbanismo, I 90-93.

Ab'Saber, A.N. 1987. A Serra do Mar na região de Cubatão: avalanches de janeiro de 1985 (A ruptura do equilíbrio ecológico na Serra de Paranapiacaba e a poluição industrial). In: Simpósio da Costa Sul e Sudeste Brasileira: síntese dos conhecimentos, Cananéia, 1987, Academia de Ciências do Estado de São Paulo, v.2, p. 74-116.

Aubert, G. \& Boulaine, J. 1967. La Pédologie. Paris, Presses Universitaires De France, $129 \mathrm{pp}$

Augusto, O. Fº; Cerri, L.E.S.; Amenomori, C.J. 1990. Riscos geológicos: aspectos conceituais. In: Simpósio Latino-Americano sobre Risco Geológico Urbano, I, São Paulo, 1990, Anais... São Paulo, ABGE, p. 352-358.

Bigarella, J.J. \& Mousinho, M.R. 1965. Considerações a respeito dos terraços fluviais, rampas de colúvio e várzeas. Boletim Paranaense de Geografia, 16/17:117-153.

Blight, G.E. 1991. Theme lecture: tropical processes causing rapid geological change. In: Forster, A. et al. eds. Quaternary Engineering Geology. Geological Society Engineering Geology Special Publication $n^{\circ} 7$, Londres, p. 459-471.

Cailleux, A. \& Tricart, J. 1956. Le problème de la classification des faits géomorphologiques. Annales de Géographie 349:162-186.
Castri, F. D. 1980. O toque humano. O Correio da Unesco, 8:20-24.

Chasin, J. 1995. Marx: Estatuto Ontológico e Resolução Metodológica. In: Teixeira, F.J.S., Pensando com Marx, São Paulo, Ed. Ensaio, p. 335-537.

Coutinho, P.T. \& Negro, A. Jr. 1995. Túneis não tripulados - Parte 2: o Slurry Pipe-Jacking. In: Simpósio sobre Túneis Urbanos, São Paulo, 1995, Coletânea... São Paulo, ABGE/CBT, p. 231-246.

Cozzolino, V.M.; Martinati, L.G.; Buono, A.V.D. 1994. Contribuição ao estudo dos movimentos tectônicos sin e pós-sedimentares na Bacia de São Paulo a partir de evidências observadas nas escavações do túnel da Eletropaulo. Solos e Rochas, 17:13-29.

Dean, W. 1996. Aferro e fogo: a história e a devastação da Mata Atlântica Brasileira. São Paulo, Cia. das Letras, 484p.

Diacov, V. \& Covalev, S. 1965. História da Antiguidade (Primeiro Volume: sociedade primitiva e oriente). Ed. Fulgor, São Paulo, 343 p.

Engels F. 1991. A dialética da natureza. 5a. ed., Rio de Janeiro, Ed. Paze Terra, 238 p. (obra escrita entre 1872-1882).

Erhart, H. 1956. La génese dês sois en tant que phénomène géologique. Masson et Cie Éditeurs, Paris, $90 \mathrm{p}$.

Erhart, H. 1966. A teoria bio-resistática e os problemas biogeográficos e paleobiológicos. Notícia Geomorfológica, VI (1 1):51-58.

Eschwege, W.L. 1979. P luto Brasiliensis. Belo Horizonte / São Paulo, Edusp / Liv. Itatiaia Ed., v.l., 222p.

Fanning, D.J. \& Fanning, M.C.B. 1989. Soil: morphology, genesis and classification. New York, John Wiley \& Sons, 395p.

França, A. 1958. O quadro climato-botânico. In: Azevedo, A (coord.) A Cidade de São Paulo, São Paulo, Cia. Editora Nacional, v. I, p. 70-111.

Frederico, C. 1995. O jovem Marx (1843-44: As origens da ontologia do ser social). São Paulo, Cortez Editora, 212p.

Fúlfaro, V.J.; Ponçano, W.L.; Bistrichi, C.; Stein, D.P. 1976. Escorregamentos de Caraguatatuba: expressão atual e registro na coluna sedimentar da planície costeira adjacente. In: Congresso Brasileiro de Geologia de engenharia, 1, Rio de Janeiro, Anais... ABGE, v.2., p.341-350.

Gerasimov, I.P \& Velichko, A.A. 1984. Complex paleogeographical atlasses-monographs for the Anthropogene, and their prognostic value. In: International Geological Congress, 27, Moscou, 1984, Proceedings... Utrecht, VNU Science Press, v. 3, p. 129-154.

Goudie, A. 1990. The human impaci on the natural environment. $3^{\mathrm{a}}$ ed., Oxford, Blackwell Publishers, 388p. 
Hols, H.H.; Kofler, W.A.; Abendroth, W. 1969. Conversando com Lukács. Rio de Janeiro, $1^{\text {a }}$. ed., Ed. Paz e Terra, 218 p (entrevistas concedidas por Lukács em 1966).

Katz, C. 1996. Marx e a tecnologia. In: Coggiola, O. (org.), Marx e Engels na História, São Paulo, Xamã Editora, p.399-416 (Humanitas Publicações FFLCH).

Kowalski, W.C. 1984. History of changes of geological environment under the influence of the activity of mankind. In: International Geological Congress, 27, Moscou, 1984, Proceedings... Utrecht, VNU Science Press, v. 17, p. 51-67.

Lukács, G. 1979. Ontologia do ser social (A falsa e a verdadeira ontologia de Hegel). São Paulo, Livraria Editora Ciências Humanas, 171p.

Lukács, G. (sem data). O trabalho como posição teleológica (Capitulo da "Ontologia do Ser Social"). (Tradução de C. N. Coutinho, rnineo., inédito).

Magalhães, A.P. Jr.; Souza, C.J.O.; Marques, M.R.; Moura, M.T.T.; Moreira, P.F.; Silveira, J.S., Valadão, R.C. 1992. Modificações no padrão de sedimentacão fluvial durante o Quaternário tardio no Espinhaço meridional. In: Congresso Brasileiro de Geologia, 37, São Paulo, Boletim de Resumos Expandidos... SBG, v.2, p.306-307.

Melo, M.S. \& Ponçano, W. L. 1983. Génese, distribuição e estratigrafla dos depósitos cenozóicos no Estado de São Paulo. São Paulo, Instituto de Pesquisas Tecnológicas do Estado de São Paulo (publicação IPT1364), $74 \mathrm{p}$.

Mendes, J.C. 1984. Elementos de Estratigrafia. São Paulo, T.A. Queiroz Editor/EDUSP, $566 \mathrm{p}$

Mészáros, I. 1981. Marx: a teoria da alienação. Rio de Janeiro, Zahar Editores.

Moraes, A.C.R. 1994. Meio ambiente e ciências humanas. São Paulo, Ed. Hucitec, $100 \mathrm{p}$.

Moreira, R. 1990. Formação do espaço agrário brasileiro. São Paulo, Ed. Brasiliense, $83 \mathrm{p}$.

Moura J.R.S; Mello, C.L.; Silva, T.M; Peixoto, MN.O 1992 "Desequilíbrios ambientais" na evolução da paisagem: o Quaternário Tardio no Médio Vale do Rio Paraíba do Sul. In: Congresso Brasileiro de Geologia, 37, São Paulo, Boletim de Resumos Expandidos... SBG, v.2., p. 309-310

Nakazawa, V.A.; Freitas, C.G.L.; Diniz, N.C. 1994a. Carta Geotécnica do Estado de São Paulo (Escala 1:500.000). In: Congresso Brasileiro de Nakazawa, V.A.; Freitas, C.G.L.; Diniz, N.C. 1994b. Carta Geotécnica do Estado de São Paulo - Escala 1:500.000. 1ª ed., São Paulo, Instituto de Pesquisas Tecnológicas do Estado de São Paulo (Publicação IPT 2089), 22 p., mapas.

Oliveira, A.M.S. 1990. Depósitos tecnogênicos associados à erosão atual. In Congresso Brasileiro de Geologia de Engenharia, 6, 1990, Salvador, Atas... ABGE, v. 1, p. 411-415.

Oliveira, A.M.S.; Queiroz, J.P.,Neto; Carlstron, C.Filho; Salomão, F.X.T.; Kertzman, F.F. 1992. Depósitos tecnogênicos no Planalto Ocidental Paulista: exemplos de Andradinae Bauru. In: Congresso da ABEQUA 3,1992, Belo Horizonte, Anais... ABEQUA, p. 88-95.

Oliveira, A.M.S. 1994. Depósitos tecnogênicos e assoreamento de reservatórios. Exemplo do reservatório de Capivara, Rio Paranapanema, SP/RJ. São Paulo, v. 1, 211 p. (Tese de Doutoramento, Faculdade de Filosofia, Letras e Ciências Humanas, Universidade de São Paulo).

Oliveira, A.M.S. 1995. A abordagem geotecnogênica: a Geologia de Engenharia no Quinário. In: Bitar, O.Y. (coord.) Curso de Geologia Aplicada ao Meio Ambiente, São Paulo, IPT/ABGE, p.231-241.

Oliveira, A.M.S.; Bitar, O.Y.; Fornasari, N.F 1995. Geologia de Engenharia e Meio Ambiente. In: Bitar, O.Y. (coord.) Curso de Geologia Aplicada ao Meio Ambiente. São Paulo, IPT/ABGE, p.7-15.

Oliveira, M.C. \& Figueirôa, S.F.M. 1984. Enchentes em São Paulo, um problema do século passado (Comentário do relatório de 1887 do Eng ${ }^{\circ}$. Bianchi Betoldi). Revista IG, 5:55-58.

Peloggia, A.U.G. 1994. As coberturas remobilizadas: depósitos tecnogênicos de encostas urbanas no Município de São Paulo. Solos e Rochas, 17(2):125-129.

Peloggia, A.U.G. \& Silva, F.A.N. 1994. Escorregamentos induzidos e ocupação de encostas: um aspecto de Geologia Urbana no Município de São Paulo (SP). In: Congresso Brasileiro de Geologia de Engenharia, 38, Camboriú, 1994, Boletim de Resumos Expandidos... SBG, v. 1:510-513.

Peloggia, A.U.G. 1995. A Dialética da Geologia (Temas de Geologia inspirados na obra de Friedrich Engels, e suas aplicações). Revista Brasileira de Geociências, 25:107-110.
Peloggia, A.U.G. 1996. Delineação e Aprofundamento temático da Geologia do Tecnógeno do Município de São Paulo (As consequências geologicas da ação do homem sobre a natureza e as determinaçóes geológicas da ação humana em suas particularidades referentes à precária ocupação urbana). São Paulo, 262p. (Tese de Doutoramento, Instituto de Geociências da Universidade de São Paulo).

Petri, S. \& Suguio, K. 1971. Características granulométricas dos materiais de escorregamentos de Caraguatatuba, São Paulo, como subsídio para o estudo da sedimentação neocenozóica no Sudeste Brasileiro. In: Congresso Brasileiro de Geologia, 25, São Paulo, Resumos das Comunicações... São Paulo, SBG, p. 199-200.

Prandini, F.L.; Guidicini, G.; Grehs, S.A. 1974. Geologia Ambiental ou de Planejamento. São Paulo, Associação dos Geógrafos Brasileiros, p. 31-57,1977 (Seleção de Textos n.2).

Prandini, F.L.; Ávila, I.G.; Costanzo, J.C. Jr.; Carlston, C. F.; Bottura, J.A. Teixeira, A.L. 1978. Uma Carta geotécnica dos terrenos adjacentes ao canal do Rio Tietê, entre Osasco e Guarulhos. In: Congresso Brasileiro de Geologia de Engenharia, 2, São Paulo, Anais... ABGE, v.1, p.281-296.

Rego, L. F..M. 1933. As formações cenozóicas de São Paulo. Anuário da Escola Politécnica de São Paulo (II ano, 2a. série), p. 231-267.

Riccomini, C. 1989.0 Rift continental do Sudeste do Brasil. São Paulo, 265p. (Tese de Doutoramento, Instituto de Geociências da Universidade de São Paulo).

Riccomini, C.; Turcq, B.J.; Suguio, K. 1991. The record of continental sedimentation in southeastern Brazil during the last millenium: paleoseismicity, the Little Ice Age and man. Anais da Academia Brasileira de Ciências 63:90.

Riccomini, C. \& Coimbra, A. M. 1992. Geologia da Bacia Sedimentar. In NEGRO, A. et al. eds. Solos da Cidade de São Paulo, São Paulo, ABMS/ABEF, p.37-94.

Riccomini, C.; Coimbra, A.M.; Takiya, H. 1992. Tectônica e sedimentação na Bacia de São Paulo. In: Problemas Geológicos e Geotécnicos na Região Metropolitana de São Paulo, São Paulo, 1992, Atas... ABAS/ABGE/SBG-SP, p. 21-45.

Rocha, H.C. \& Celestino, T.B. 1992. Conhecimentos recentes sobre a Bacia de São Paulo e o projeto de construção de túneis. In: Problemas Geológicos e Geotécnicos na região Metropolitana de São Paulo, São Paulo, 1992, Atas... ABAS/ABGE/SBG-SP, p. 97-113.

Ross, J.L.S. 1991. Geomorfologia -Ambiente e Planejamento. $2^{\circ}$ ed., São Paulo, Ed. Contexto, 85p.

Ross, J.L.S. 1992. O registro cartográfico dos fatos geomórficos e a questão da taxonomia do relevo. Revista do Departamento de Geografia, FFLCH-USP, 6:17-29.

Rougerie, G. 1971. Geografia das Paisagens. São Paulo, Difusão Europeia do Livro, 134p.

Salles, W.M. 1978. O Brasil e os minerais: algumas considerações sobre o panorama mineraria no Brasil. São Paulo, Fundação João Moreira Salles, 93p.

Sampaio, A.F.C.; Pivetti, J.L.; Botter, M.A. 1992. Problemas geotécnicos em obras de galerias urbanas - a reconstrucão da galeria sob a Avenida Nove de Julho. In: Problemas Geológicos e Geotécnicos na região Metropolitana de São Paulo, São Paulo, 1992, Atas... ABAS/ABGE/SBG-SP, p. 115-132.

Santos, M. 1989. Renovando o pensamento geográfico. In: D'Incao, M.A. (org.), História e Ideal: ensaios sobre Caio Prado Jr.. São Paulo, Ed. Brasiliense / Ed. UNESP / Secretaria de Estado da Cultura, p. 419-433.

Suguio, K. \& Bigarella, J.J. 1990. Ambientes Fluviais. Florianópolis, $2^{a}$ ed., Editora da UFSC/ Editora UFPR, 183p.

Takiya, H. 1997. Estudo da sedimentação neogênico-quatemária no Município de São Paulo: caracterização dos depósitos e suas implicações para a Geologia Urbana. São Paulo, 149p. (Tese de Doutoramento, Instituto de Geociências da Universidade de São Paulo).

Ter-Stepanian, G. 1988. Beginning of the Technogene. Bulletin I.A.E.G., 38:133-142.

Thiel, R. 1964. O romance da Terra. São Paulo, Ed. Melhoramentos, 337p.

Torres, S.L.; Ito, I.S.; Citroni, E.M.G.; Soares, L. 1995. Sismos induzidos por barragens. O Empreiteiro 326:29-34.

Tricart, J. 1965. Príncipes et méthodes de la Géomorphologie. Paris, Masson et Cie. Editeurs, 496p.

UNESCO 1976. Terremotos provocados pelo homem. O Correio da Unesco, 4:23.

Vaisman, E. 1989. A ideologia e sua determinação ontológica. Ensaio $17 / 18: 399-444$ 
Vargas, M. 1981. As lições dos escorregamentos da Serra do Mar. In: Encontro técnico: estabilização de taludes, São Paulo, ABMS, p. 1-17.

Vargas, M. 1992. Evolução dos conhecimentos. In: Negro, A. et al. (eds. Solos da Cidade de São Paulo, São Paulo, ABMS/ABEF, p. 1-35.

Watson, J. 1983. Geology an Man: an introduction to applied earth science. Londres, George AHen \& Unwin, $150 \mathrm{p}$.

Wolle, C.M. 1988. Análise dos escorregamentos translacionais numa região da Serra do Mar no contexto de uma classificação de mecanismos de instabilização de encostas. São Paulo, 406 p. (Tese de Doutoramento, Escola Politécnica da Universidade de São Paulo).

Wolle, C.M. 1992. Veias abertas na serra. Téchne 1:26-31.
Wolle, C.M. \& Carvalho, C.S. 1989. Deslizamentos em encostas na serra do Mar - Brasil. Solos e Rochas, 12:27-36.

Wolle, C.M. \& Silva, L.C.R. 1992. Taludes. In: Negro, A. et al. eds., Solos da Cidade de São Paulo, São Paulo, ABMS/ABEF, p. 249-277.

Yassuda, C. T.; Hori, K. Rocha, H.C. 1992. Água do subsolo. In: Negro, A. et al eds. Solos da Cidade de São Paulo, São Paulo, ABMS/ABEF, p. 111-140.

MANUSCRITO A-902

Recebido em 02 de janeiro de 1997

Revisão do autor em 05 de agosto de 1997 Revisão aceita em 10 de agosto de 1997 